\title{
Pathogenic microbial flora of genital ulcers in Sheffield with particular reference to herpes simplex virus and Haemophilus ducreyi
}

\author{
G R KINGHORN, S HAFIZ, AND M G McENTEGART \\ From the Department of Genitourinary Medicine, Royal Infirmary; and the Department of Medical \\ Microbiology, University of Sheffield Medical School, Sheffield
}

SUMMARY The pathogenic microbial flora of genital ulcers in 161 (80 men and 81 women) unselected patients was studied prospectively. In only one case was Treponema pallidum responsible whereas herpes simplex virus was considered to be the cause of $130(80 \cdot 8 \%)$ genital ulcers. $H$ ducreyi was isolated from $46(28 \cdot 6 \%)$ patients, most commonly as a secondary pathogen in herpetic lesions. Two or more pathogens were isolated from the ulcers in $67(41 \cdot 6 \%)$ patients, and in $21(13 \%)$ patients no pathogens were isolated.

Our results indicate an urgent need for antiviral treatment to reduce the local reservoir of genital herpes, challenge traditional concepts about the prevalence of $H$ ducreyi in Britain, and call for a reappraisal of its role in the causation of genital ulcers.

\section{Introduction}

Recent studies ${ }^{12}$ (unpublished data) of the microbial aetiology of genital ulceration show notable differences, particularly as regards the causes of nonsyphilitic ulcers. This may partly reflect differences in technique but also genuine geographical differences in the incidences of genital pathogens. Whereas chancroid is considered to be endemic in tropical countries $^{3}$ and genital herpes is infrequently reported, the converse is true in developed Western countries. In Britain, where chancroid has until recently been rarely diagnosed, and even then usually as an imported infection, the incidence of genital herpes has risen to epidemic levels in the past decade. The advent of reliable cultural techniques ${ }^{4} 5$ for the isolation of Haemophilus ducreyi in recent years has resulted in the reporting of localised outbreaks of chancroid in non-tropical countries ${ }^{6-9}$; recently we reported 22 cases in Sheffield ${ }^{10}$ which were confirmed by culture using a modified haemin-containing medium.

In this study, we examined the pathogenic flora of genital ulcers in men and women presenting to the department of genitourinary medicine, Royal Infirmary, Sheffield, over a 12-month period.

Address for reprints: $\operatorname{Dr}$ G $\mathbf{R}$ Kinghorn, Department of Genitourinary Medicine, Royal Hallamshire Hospital, Sheffield S10 2JF

Accepted for publication 20 June 1980

\section{Patients and methods}

One hundred and sixty-one unselected patients $(80$ men and 81 women), who presented for the first time with discrete genital ulcers between 1 December 1980 and 30 November 1981, were routinely assessed. Exudate from the bases of ulcers was examined by darkfield microscopy for the presence of Treponema pallidum and collected with cotton-tipped swabs for both tissue culture inoculation to detect herpes simplex virus and bacteriological culture for Haemophilus ducreyi, other pathogenic aerobic and anaerobic bacteria, and Candida species. In addition, all patients had blood samples taken at their first visit for syphilis serology by the rapid plasma reagin (RPR) and the Treponema pallidum haemagglutination (TPHA) tests and for the detection of herpes simplex antibodies by complement-fixation, ELISA, or neutralisation techniques. In patients returning for follow-up serological tests for herpes antibody were repeated three weeks after the initial visit and for syphilis after three weeks, six weeks, and three months.

HERPES SIMPLEX VIRUS ISOLATIONS

Specimens of ulcer exudate obtained with cottontipped swabs were immediately inserted into viral transport medium and kept in the clinic refrigerator at $4^{\circ} \mathrm{C}$ before being transferred to the laboratory, normally within four hours. There they were stored 
at $-70^{\circ} \mathrm{C}$ before being inoculated into monolayers of one or more of the following cell lines: African grey monkey (Vero), human epithelium (Hep 2), rabbit kidney (RKB), human embryo lung (Flow 2002), and hamster kidney (BHK 21). Inoculated monolayers were incubated at $37^{\circ} \mathrm{C}$ for up to 14 days and observed daily for the cytopathic effect of herpes.

In patients with negative culture results for herpes a fourfold rise in antibody titre in the convalescent sera was considered to be indicative of recent herpes simplex infection. Primary and recurrent episodes of herpes infection were distinguished by analysis of the patient's history, the severity and extent of the herpetic lesions, and the results of herpes antibody tests. Primary infections were diagnosed when there was no history of genital ulceration, there were numerous extensive skin lesions-usually bilateral and often accompanied by cervical or urethral lesions-and antibody titres were low or absent on initial serological testing. In contrast, patients with recurrent herpes almost always gave a history of episodes of genital ulceration, had few lesions usually confined to the skin, and had pre-existing antibodies at their first presentation usually at a high titre.

\section{HAEMOPHILUS DUCREYI ISOLATIONS}

Swabs containing ulcer exudate were inoculated directly at the time of examination on to two plates of modified haemin-containing medium, one of which contained $5 \%$ horse blood. The constituents of the base medium were as described ${ }^{10}$ with the addition of gelatin (Oxoid) in a concentration of 4 $\mathrm{g} / \mathrm{l}$. Inoculated plates were transported to the laboratory, normally within two hours, where they were incubated in an atmosphere containing $5 \%$ carbon dioxide at $33^{\circ} \mathrm{C}$ for up to seven days.

$H$ ducreyi isolates were initially recognised by their dark-brown colonies, which had a pronounced tendency to remain intact and could easily be distinguished from other organisms on the colourless medium. On the blood-containing medium the colonies produced $\alpha$-haemolysis. The identity of the organisms was confirmed by Gram-staining, negative catalase, $\mathrm{H}_{2} \mathrm{~S}$, indole, and carbohydrate fermentation test results, and positive test results for alkaline phosphatase and nitrate reduction. Our isolates conformed to the taxonomic requirements of Killian ${ }^{11}$ and in all respects were identical to a reference strain (NTC 10945 type strain) and only differed from strains isolated from patients with classical chancroid in South Africa (kindly supplied by $\mathrm{Dr} \mathbf{P}$ Piot, Institute Voor Tropische Geneeskunde, Antwerp, Belgium) and Kenya (kindly supplied by Dr A Ronald, Department of Medical Microbiology, Winnipeg, Manitoba, Canada) in being $\beta$-lactamase-negative when tested with chromogenic cephalosporin. All 16 isolates tested by intradermal injection of rabbits gave the pathogenic responses described by Hammond et al. ${ }^{12}$

AEROBIC AND ANAEROBIC BACTERIAL ANALYSIS Swabs of ulcer exudate were normally transferred to the laboratory before being inoculated on to blood agar media (Oxoid blood agar base plus $10 \%$ lysed horse blood) and MacConkey's medium. When a delay greater than two hours between specimen collection and media inoculation was expected, swabs were placed in Amies transport medium. Inoculated plates were incubated for up to seven days both aerobically and anaerobically. Pathogenic isolates were identified using standard methods. ${ }^{13}$

\section{Results}

Separate analysis of the isolates from ulcers in men and women gave similar results (table). At least one pathogenic agent was found in $140(87 \%)$ patients, and in $67(41.6 \%)$ patients there were two or more pathogenic organisms in their ulcer flora.

TABLE Pathogenic microbial flora isolated from the genital ulcers in 161 patients

\begin{tabular}{|c|c|c|c|}
\hline & $\begin{array}{l}\text { Men } \\
(n=80)\end{array}$ & $\begin{array}{l}\text { Women } \\
(n=81)\end{array}$ & $\begin{array}{l}\text { Total( } \%) \\
(n=161)\end{array}$ \\
\hline $\begin{array}{l}\text { Herpes simplex virus } \\
\text { Treponema pallidum } \\
\text { Haemophilus ducreyi } \\
\text { Other aerobic bacteria } \\
\text { Staphylococcus pyogenes } \\
\text { ß-haemolytic streptococci } \\
\text { Group A } \\
\text { Group B } \\
\text { Group C } \\
\text { Group G } \\
\text { Enterococci } \\
\text { Coliforms } \\
\text { Neisseria gonorrhoeae } \\
\text { Anaerobic bacteria } \\
\text { Bacteroides species } \\
\text { Anaerobic cocci } \\
\text { Candida } \text { species } \\
\text { No pathogens isolated }\end{array}$ & $\begin{array}{r}52 \\
1 \\
24 \\
20 \\
6 \\
\\
2 \\
8 \\
1 \\
4 \\
1 \\
3\end{array}$ & $\begin{array}{r}63 \\
22 \\
20 \\
6 \\
1 \\
1 \\
5 \\
1 \\
3 \\
5 \\
5 \\
1 \\
4 \\
3 \\
2 \\
14 \\
8\end{array}$ & $\begin{array}{c}115(71 \cdot 4) \\
1(0 \cdot 6) \\
46(28 \cdot 6) \\
40(24 \cdot 8) \\
12(7 \cdot 5) \\
3(1 \cdot 9) \\
13(8 \cdot 1) \\
2(1 \cdot 2) \\
7(4 \cdot 3) \\
6(3 \cdot 7) \\
8(5 \cdot 0) \\
1(0 \cdot 6) \\
9(5 \cdot 6) \\
6(3 \cdot 7) \\
5(3 \cdot 1) \\
16(9 \cdot 9) \\
21(13 \cdot 0)\end{array}$ \\
\hline
\end{tabular}

\section{HERPES SIMPLEX VIRUS}

Herpes simplex virus was the most commonly isolated pathogen; in 52 patients it was the sole pathogen. In addition to the 115 patients in whom direct virus isolation from ulcers was successful, 15 other patients had a history of recurring genital ulceration with at least one episode of genital herpes confirmed by culture before their present presentation or serological evidence of current herpes simplex infection or both. In these culture-negative 
patients it is likely that the virus was the initiating cause of their genital ulceration. Thus, a total of 130 $(80.8 \%)$ patients had genital herpes, of whom $78 \mathrm{had}$ primary episodes and 52 recurrent episodes.

\section{TREPONEMA PALLIDUM}

$T$ pallidum was the cause of genital ulceration in only one patient; he had acquired his infection in Mexico. No other patients had clinical, microscopical, or serological evidence of syphilis either at initial presentation or at subsequent follow-up.

\section{HAEMOPHILUS DUCREYI}

The commonest bacterial pathogen was $H$ ducreyi, but in almost all of 46 patients infected with this organism there was evidence of a separate initiating cause for their genital ulcers; in 38 patients the organism was found in the lesions of genital herpes. Although $H$ ducreyi was the sole pathogen isolated from ulcers in 10 patients, seven of these had a known history of recurrent genital herpes and the other three had secondary infection of ulcers caused by trauma, Behçet's syndrome, and excoriated penile psoriasis. The frequency of $H$ ducreyi isolation was not appreciably different in patients with either herpetic or non-herpetic genital ulceration. The organism was isolated in $24(30.8 \%)$ of 78 patients with primary herpes, $14(26.9 \%)$ of 52 patients with recurrent herpes, and eight $(25 \cdot 8 \%)$ of 31 patients with non-herpetic ulceration.

$H$ ducreyi was found in the ulcers of nine $(47 \%)$ of 19 patients who had had sexual contacts in countries outside Britain in the four weeks before presentation compared with $37(26 \%)$ of 142 who had had local contacts only; most $\boldsymbol{H}$ ducreyi infections had apparently been acquired locally. Moreover, in only two patients had there been contact with a known case of chancroid. Although ulcers containing $\boldsymbol{H}$ ducreyi were invariably tender with a purulent or necrotic base clinical features varied. Multiple ulcers (74\%) and lymphadenitis $(\mathbf{7 0 \%})$ were common in patients with $\boldsymbol{H}$ ducreyi infection but there was no case of bubo formation in this series.

\section{OTHER AEROBIC BACTERIA}

Other important aerobic bacteria were isolated from genital ulcers in $\mathbf{4 0}$ patients, but in only eight were they the sole pathogens isolated.

Only Staphylococcus pyogenes and $\beta$-haemolytic streptococci appeared to be primary pathogens. In the one patient in whom Neisseria gonorrhoeae was isolated from a vulval ulcer, herpes simplex virus and $H$ ducreyi were isolated from the same genital lesion. It is, therefore, unlikely that she had true cutaneous gonorrhoea.
Anaerobic bacteria were never found in the absence of other microbiological causes of genital ulceration but may have had a secondary pathogenic role in some patients.

Candida species appeared to be secondary invaders of herpetic lesions in 11 patients but in five they may have intitiated genital ulceration by causing pruritus which lead to subsequent excoriation.

\section{Discussion}

In common with other recent studies we have found that genital ulcers often have a polymicrobial flora and frequently contain two or more pathogens. We found no obvious sex bias in the distribution of the major pathogens.

Herpes simplex virus was the most common isolate and probably the initiating cause of genital ulceration in $81 \%$ of our patients. This is a much higher frequency than in other studies and contrasts with $31-40 \%$ reported in North American studies, ${ }^{114}$ and only $4 \%$ in Kenya. ${ }^{2}$ Although the rapid increase in locally diagnosed cases of genital herpes during the past 10 years results partially from increased clinical awareness and improved methods of virus isolation, in the main the rise simply reflects the natural history of a condition where recurrences are common and effective treatment lacking. In Sheffield we have also found a high prevalence of HSV type 1 isolates ${ }^{15}$ (possibly related to changes in sexual practice), contributing to the ever-increasing reservoirs of genital herpes in the community.

Infectious syphilis is rare within our relatively stable population because contact tracing and effective treatment of the few sporadic cases seen in recent years has rapidly removed the local reservoir of infection. It is interesting to compare the single case of imported treponemal ulceration in this study with the reported frequencies of $17 \%$ in Denver, ${ }^{1}$ $12 \%$ in Seattle (unpublished data), and $11 \%$ in Kenya. $^{2}$

$H$ ducreyi was isolated from the genital ulcers of $28 \%$ of our patients, which compares with $1-2 \%$ in recent American studies ${ }^{1}$ and $60 \%$ in Kenya. ${ }^{2}$ In most infected patients the organism appeared to be a secondary invader rather than a primary pathogen. The sex distribution of infections was about equal and the great majority were locally acquired. As only two cases were linked, clearly our results were not simply due to a local outbreak of chancroid, although a local reservoir of individuals with asymptomatic genital carriage of $\boldsymbol{H}$ ducreyi may well exist. This view conflicts with the observations of others, ${ }^{2} 616$ but evidence to support our contention was found in this study. In three men, all of whom presented initially with ulcers infected both with 
herpes simplex virus and $H d u c r e y i$, we were able to re-isolate $\boldsymbol{H}$ ducreyi from the preputial swabs after their ulcers had completely healed. All had been treated with saline washes alone. In a separate study, we have isolated $H$ ducreyi from endocervical swabs taken from 11 women and the preputial swabs from three men, most of whom had no history of genital ulceration and none of whom had current genital ulcers.

Organisms resembling $H$ ducreyi have been seen on smears from chancroidal ulcers in previous studies, ${ }^{17} 18$ and recently Ursi et al ${ }^{19}$ described a "ducreyilike bacillus", which they isolated from genital ulcers in 25 of 155 patients in Swaziland. This organism differed from $H$ ducreyi in that it preferred a microaerophilic atmosphere, did not require $\mathrm{X}$ factor for growth, produced hydrogen sulphide and xylose fermentation, but gave a negative result to the alkaline phosphatase test. In another recent study Caine et al (unpublished data) suggested that Haemophilus influenzae and Haemophilus parainfluenzae may cause some genital ulcers. We did not routinely examine stained smears from ulcers, because of the low specificity and sensitivity of this investigation, and are satisfied that our isolates were indeed $H$ ducreyi, which have a high requirement for haemin and share identical cultural and biochemical characteristics with test strains of the organism. Our local strains may possibly have had a lower pathogenicity in humans than those found in the tropics, although we have so far failed to show any diminished pathogenicity in rabbits. We are aware that strains isolated from typical cases of chancroid in Africa are frequently $\beta$-lactamase producers $^{20}$ whereas our local strains are not; we are, therefore, investigating them for other possible differences in plasmid content and antimicrobial sensitivity. Although our methods for isolating other aerobic and anaerobic bacteria were less sensitive than in other studies, ${ }^{114}$ which detected commensal as well as pathogenic organisms, we nevertheless found bacteria other than $H$ ducreyi, which were fairly common secondary invaders of ulcers caused by herpes simplex virus and trauma but were relatively rare as primary pathogens. In some cases antibiotic treatment was necessary to eradicate these organisms and so ensure healing of the ulcer.

This study shows that the most frequent initiating cause of genital ulceration in Sheffield is herpes simplex virus and that herpetic lesions are frequently subject to secondary infection with $H$ ducreyi and other bacteria. The immediate and long-term morbidity associated with genital herpes makes accurate diagnosis essential, and the increasing local reservoir of genital herpes in this community necessitates the urgent development of effective antiviral treatment.

We are particularly grateful to the medical and nursing staff of the department of genitourinary medicine for their co-operation in collecting specimens; Dr I Barton, the staffs of the Sheffield Public Health Service, and the department of bacteriology, Royal Hallamshire Hospital, for microbiological assistance; and Elise Welsh and Hazel Bland for their secretarial help.

\section{References}

1. Chapel T, Brown WJ, Jeffries C, Stewart JA. The microbiological flora of penile ulcerations. $J$ Infect Dis 1978; 137: 50-6.

2. Nsanze H, Fast MV, D'Costa LJ, Tukei P, Curran J, Ronald AR. Genital ulcers in Kenya: clinical and laboratory study. Br J Vener Dis 1981;57:378-81.

3. Gaisin A, Heaton CL. Chancroid: alias the soft chancre. Int $J$ Dermatol 1975; 14:188-97.

4. Sottnek FO, Biddle JW, Kraus SJ, Weaver RE, Stewart JA Isolation and identification of Haemophilus ducreyi in a clinical study. J Clin Microbiol 1980; 12: 170-4.

5. Hammond GW Lian CJ, Wilt JC, Ronald AR. Comparison of specimen collection and laboratory techniques for isolation of Haemophilus ducreyi. J Clin Microbiol 1978;7:39-43.

6. Lykke-Olsen L, Larsen L, Pedersen TG, Gaarslev K. Epidemic of chancroid in Greenland 1977-78. Lancet 1979; i:654-5.

7. Nayyar KC, Stolz E, Michel MF. Rising incidence of chancroid in Rotterdam: epidemiological, clinical, diagnostic and therapeutic aspects. Br J Vener Dis 1979;55:439-41.

8. Hammond GW, Slutchuk M, Scatliff J, Sherman E, Wilt JC Ronald AR. Epidemiologic, clinical, laboratory and therapeutic features of an urban outbreak of chancroid in North America. Rev Infect Dis 1980; 2:867-9.

9. Handsfield $\mathrm{HH}$, Totten PA, Fennel CL, Falkow S, Holme KK. Molecular epidemiology of Haemophilus ducrey infections. Ann Intern Med 1981;95:315-8.

10. Hafiz S, Kinghorn GR, McEntegart MG. Chancroid in Sheffield: a report of 22 cases diagnosed by isolation of Haemophilus ducreyi in a modified medium. Br J Vener Dis 1981;57:382-6.

11. Killian M. A taxonomic study of the genus Haemophilus with the proposal of a new species. J Gen Microbiol 1976;93:9-62.

12. Hammond GW, Lian CJ, Wilt JC, Ronald AR. Antimicrobial susceptibility of Haemophilus ducreyi. Antimicrob Agents Chemother 1978; 13:608-12.

13. Cowan and Steel's Manual for the Identification of Medical Bacteria, 2nd ed. Cambridge: Cambridge University Press. 1974.

14. Barile MF, Blumberg JM, Kraul CW, Yaguchi R. Penile lesions among US Armed forces personnel in Japan. Arch Dermatol 1962;86:273-81.

15. Barton IG, Kinghorn GR, Najem S, Al-Omar LS, Potter CW Incidence of HSV-I and HSV-2 isolated from a group of patients with herpes genitalis in Sheffield. $B r J$ Vener Dis 1982;58:44-7.

16. Ronald AR, Wilt JC, Albritton WL. Haemophilus decreyi. In Non-gonococcal Urethritis and Other Sexually Transmitted Diseases. Geneva: WHO 1978.

17. Deacon WE, Albritton DC, Olansky S, Kaplan W. VDRL chancroid studies. I A simple procedure for the isolation and identification of Haemophilus ducreyi. J Invest Dermato 1956; 26: 399-406.

18. Leibovitz A. An oubreak of pyogenic penile ulcers associated with a microaerophilic streptococcus resembling Haemophilus ducreyi. Am J Syph Gonorr Vener Dis 1954;38:303-15.

19. Ursi JP, van Dyck E, Ballard RC, Jacob W, Piot P, Meheu AZ. Characterisation of an unusual bacterium isolated from genital ulcers. J Gen Microbiol 1982; 15:97-103.

20. Maclean IW, Bowden GHW, Albritton HL. TEM type $\beta$-lactamase production in Haemophilus ducreyi. Antimicrob Agents Chemother 1980; 17: 897-900. 